Article

\title{
New Insights into the Chemical Reactivity of Dry-Cured Fermented Sausages: Focus on Nitrosation, Nitrosylation and Oxidation
}

\author{
Aline Bonifacie ${ }^{1,2}$, Philippe Gatellier ${ }^{1}$, Aurélie Promeyrat ${ }^{3}$, Gilles Nassy ${ }^{3}$, Laurent Picgirard ${ }^{4}$, \\ Valérie Scislowski ${ }^{4}$, Véronique Santé-Lhoutellier ${ }^{1}$ (D) and Laetitia Théron ${ }^{1, *}$ \\ 1 Institut National de Recherche Pour l'Agriculture, l'Alimentation et l'Environnement (INRAE), \\ UR370 Qualité des Produits Animaux, F-63122 Saint Genès-Champanelle, France; \\ Aline.Bonifacie@inrae.fr (A.B.); philippe.gatellier@inrae.fr (P.G.); veronique.sante-lhoutellier@inrae.fr (V.S.-L.) \\ 2 IFIP_-Institut du Porc, 7 Avenue du Général De Gaulle, F-94700 Maisons Alfort, France \\ 3 IFIP-Institut du Porc, La Motte au Vicomte, BP 35104, F-35561 Le Rheu CEDEX, France; \\ aurelie.promeyrat@ifip.asso.fr (A.P.); Gilles.Nassy@ifip.asso.fr (G.N.) \\ 4 Association Pour le Développement de l'Industrie de la Viande (ADIV), 10, Rue Jacqueline Auriol, \\ F-63039 Clermont-Ferrand, France; laurent.picgirard@adiv.fr (L.P.); Valerie.Scislowski@adiv.ar (V.S.) \\ * Correspondence: laetitia.theron@inrae.fr
}

Citation: Bonifacie, A.; Gatellier, P. Promeyrat, A.; Nassy, G.; Picgirard, L.; Scislowski, V.; Santé-Lhoutellier, V.; Théron, L. New Insights into the Chemical Reactivity of Dry-Cured

Fermented Sausages: Focus on Nitrosation, Nitrosylation and Oxidation. Foods 2021, 10, 852. https://doi.org/10.3390/ foods10040852

Academic Editors: Mario Estévez and Youling Xiong

Received: 15 March 2021

Accepted: 10 April 2021

Published: 14 April 2021

Publisher's Note: MDPI stays neutral with regard to jurisdictional claims in published maps and institutional affiliations.

Copyright: (c) 2021 by the authors. Licensee MDPI, Basel, Switzerland. This article is an open access article distributed under the terms and conditions of the Creative Commons Attribution (CC BY) license (https:// creativecommons.org/licenses/by/ $4.0 /)$.

\begin{abstract}
Nitrite and nitrate are added to cured meat for their bacteriological, technological and sensorial properties. However, they are suspected to be involved in the formation of nitroso compounds (NOCs), such as potentially mutagenic nitrosamines, nitrosylheme and nitrosothiols. Controlling the sanitary and sensorial qualities of cured meat products by reducing these additives requires elucidating the mechanisms involved in the formation of NOCs. To this end, we studied the dose-response relationship of added sodium nitrite and/or sodium nitrate $(0 / 0,80 / 80,0 / 200$, and 120/120 ppm) on the formation of NOCs in dry cured fermented sausages. The results showed a basal heme iron nitrosylation in the absence of $\mathrm{NaNO}_{2} / \mathrm{NaNO}_{3}$ due to starter cultures. This reaction was promoted by the addition of $\mathrm{NaNO}_{2} / \mathrm{NaNO}_{3}$ in the other conditions. Reducing the dose to $80 / 80 \mathrm{ppm}$ still limits lipid oxidation without the formation of non-volatile nitrosamines. Conversely, the addition of $\mathrm{NO}_{2} / \mathrm{NO}_{3}$ slightly increases protein oxidation through higher carbonyl content. The use of $80 / 80$ ppm could be a means of reducing these additives in dry-cured fermented meat products.
\end{abstract}

Keywords: nitrite; nitrate; cured meat; dry-cured fermented sausage; nitrosamine; nitrosylheme; nitrosothiol; oxidation

\section{Introduction}

Dry-cured fermented sausages are one of the main cured meat products consumed in France [1]. The combined use of nitrite and/or nitrate is characteristic of such fermented products. The addition of nitrate, knowing that it will be reduced to nitrite, is a traditional curing method [2]. Nitrite and nitrate are added in meat products for their bacteriological and organoleptic properties. Indeed, nitrite prevents the growth of pathogenic bacteria, such as strains of Salmonella typhimurium and Clostridium botulinum [3,4]. In addition, nitrite is used during curing processes for its antioxidant capacity, promoting product conservation [5]. The antioxidant properties of nitrite can also prevent the formation of aldehydes, some of which are mutagenic, due to lipid peroxidation during the curing process [6]. Moreover, nitrite gives cured meat products their characteristic color and flavor $[2,3,7]$.

Nevertheless, besides these positive effects, nitrite and nitrate are involved in the formation of various nitroso compounds (NOCs), and so their use is controversial. Indeed in oxidative and low $\mathrm{pH}$ conditions, nitrite can react with compounds such as secondary 
amines (through $\mathrm{N}$-nitrosation reaction) to form nitrosamines, some of which are mutagenic [8]. This mutagenicity is due to their degradation into reactive compounds which can cause DNA adducts [9]. In reducing medium, nitrite can also react with the heme iron from myoglobin to form nitrosylheme (through nitrosylation reaction), which gives cured meat its red color [7]. During digestion, nitrosylheme can release NO which could participate in the formation of nitrosamines [10], but this is still a subject of debate [11]. Finally, nitrite can react with free thiol groups (through S-nitrosation reaction) to form nitrosothiols [10]. Nitrosothiols are not dangerous by themselves, but upon digestion they can transfer their NO groups to heme iron and to secondary amines to form nitrosylheme and nitrosamines, respectively [10].

This chemical reactivity, namely nitrosation, nitrosylation and oxidation reactions, can be impacted by the specific technological process used in dry cured fermented meat products. Indeed, these products need several weeks of drying-ageing, according to sausage size and quality schemes [12]. The early stage of the drying-ageing step (fermentation stage) allows the development of the specific technological starter added during batter elaboration. These microorganisms play a role in the sanitary quality and conservation of dried products [2] and have a nitrate-reducing activity [13,14]. Moreover, the drying process reduces water activity (aw) and is accompanied by a reduction of $\mathrm{pH}[2,15]$ while, proteolysis and lipolysis occur during aging. Proteolysis and lipolysis are the major biochemical reactions leading to the formation of aroma and flavor precursors in fermented meats [16]. Proteolysis is also implicated in the $\mathrm{S}$ - and $\mathrm{N}$-nitrosation process by promoting the release of peptides and free amino acids. Nitrosation in large-size proteins remains very low due to steric hindrance and potential denitrosation by certain surrounding residues [17].

Therefore, it is of great importance to take into account this specificity to reduce the use of additives, knowing that in France, the maximum authorized doses are 120 ppm of sodium nitrite plus $120 \mathrm{ppm}$ of sodium nitrate or $200 \mathrm{ppm}$ of sodium nitrate for products dried during more than 3 weeks [12]. Thus, the aim of this study is to elucidate the reactions and interactions implicated in the formation of NOCs and the oxidation of lipids and proteins in dry-cured fermented meat products, with regard to adding doses of nitrite/nitrate. The effect of modulating added nitrite and/or nitrate concentrations in dry cured fermented sausages is explored. The chemical reactivity of precursors and catalysts in the formation of nitroso compounds and lipid and protein oxidation products is evaluated.

\section{Materials and Methods}

\subsection{Reagents}

All the reagents, i.e., acetone, ascorbate, ethanol, ferrozine, hydrochloric acid, thiobarbituric acid, and the Griess reagent kit for nitrite and nitrate assays (ref: 23479-1KT-F) were purchased from Sigma Aldrich (Saint Louis, MO, USA). The Vivaspin ${ }^{\circledR} 2$ system (PES membrane with a cut-off of $5 \mathrm{kDa}$ ) (ref: VS0212) and the syringe filters with $0.22 \mu \mathrm{m}$ regenerated cellulose membranes (ref: 17761) were purchased from Sartorius (Göttingen, Germany).

\subsection{Preparation of Dry-Cured Fermented Meat Samples}

The elaboration process is summarized in Figure 1. Dry-cured fermented sausages were made from mixing pieces of porcine shoulders (obtained from Tradival, Lapalisse, France) and back fat at the Technical Institute ADIV (Clermont-Ferrand, France). The shoulders were defatted, skinned, denerved and deboned. After mixing and grinding, commercial starter cultures and ingredients were added (Table 1). The starter culture (Lallemand, France) was a mix of Lactobacillus sakei, Staphylococcus carnosus and Staphylococcus xylosus. 


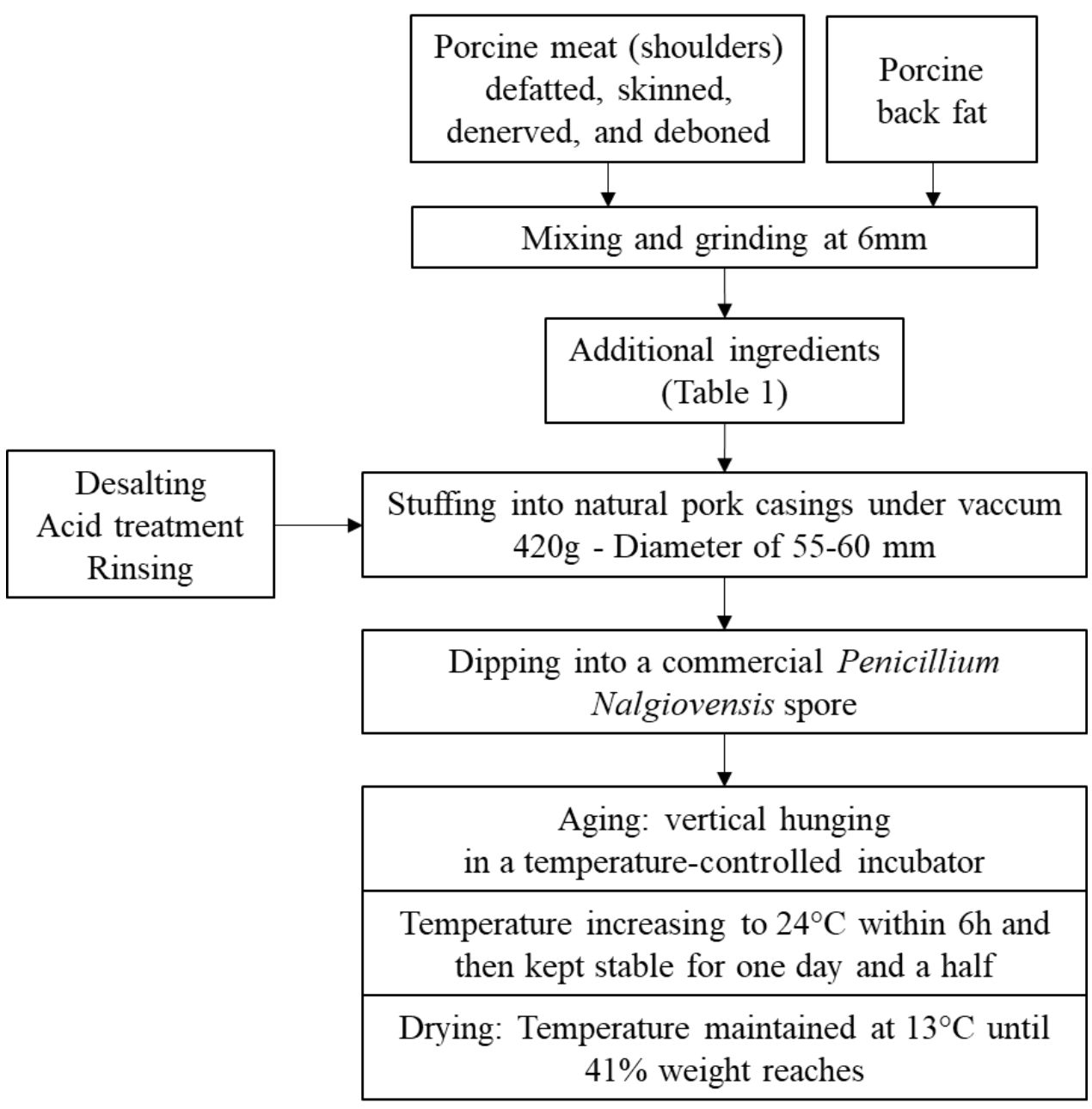

Figure 1. Elaboration process of dry-cured fermented sausages.

Table 1. Composition of dry-cured fermented sausages ( $\mathrm{g} / \mathrm{kg}$ or \%o of mixed meat-fat).

\begin{tabular}{|c|c|c|c|c|}
\hline & $0 \mathrm{NO}_{2} / \mathrm{NO}_{3}$ & $80 \mathrm{NO}_{2} / \mathrm{NO}_{3}$ & $200 \mathrm{NO}_{3}$ & $120 \mathrm{NO}_{2} / \mathrm{NO}_{3}$ \\
\hline Meat (shoulders) & \multicolumn{4}{|c|}{870} \\
\hline Back fat & \multicolumn{4}{|c|}{130} \\
\hline Ferment GY2 & \multirow{2}{*}{\multicolumn{4}{|c|}{0.15}} \\
\hline $\begin{array}{c}\text { (Lb. sakei, S. carnosus, } \\
\text { S. xylosus) }\end{array}$ & & & & \\
\hline Ground grey pepper & \multicolumn{4}{|c|}{1.50} \\
\hline Dextrose & \multicolumn{4}{|c|}{5.50} \\
\hline Lactose & \multicolumn{4}{|c|}{6.00} \\
\hline Natural salt $(\mathrm{NaCl})$ & 26.00 & 12.67 & 26.00 & 6.00 \\
\hline Nitrite salt $\left(0.6 \%\right.$ of $\left.\mathrm{NaNO}_{2}\right)$ & 0.00 & 13.33 & 0.00 & 20.00 \\
\hline Potassium nitrate $\left(\mathrm{KNO}_{3}\right)$ & 0.00 & 0.10 & 0.24 & 0.14 \\
\hline
\end{tabular}

Current industrial formulations include sodium nitrate alone (expressed as $\mathrm{NaNO}_{3}$ ) or a mixture of sodium nitrite and sodium nitrate (expressed as $\mathrm{NaNO}_{2}$ and $\mathrm{NaNO}_{3}$ respectively). In the following publication, $0 \mathrm{NO}_{2} / \mathrm{NO}_{3}$ corresponded to a control without sodium nitrite/sodium nitrate added. The added dose of $80 \mathrm{ppm}$ of $\mathrm{NaNO}_{2}$ and $80 \mathrm{ppm}$ of $\mathrm{NaNO}_{3}\left(80 \mathrm{NO}_{2} / \mathrm{NO}_{3}\right)$ corresponded to a reasonably safe rate at the sanitary level [3] and is the short-term objective for industrial production. The addition of $120 \mathrm{ppm}$ of $\mathrm{NaNO}_{2}$ and $120 \mathrm{ppm} \mathrm{NaNO}\left(120 \mathrm{NO}_{2} / \mathrm{NO}_{3}\right)$ and $200 \mathrm{ppm}$ of $\mathrm{NaNO}_{3}\left(200 \mathrm{NO}_{3}\right)$ corresponded to the maximum authorized by the French Code of Practice [12] for products with nitrite and nitrate, respectively. For each condition studied, the concentration in equivalent $\mathrm{mM}$ 
of total NO added is presented in Table 2 for comparison with data from the literature. Moreover, the concentrations of nitrite, nitrate, nitrosothiols and nitrosamines expressed in ppm are also expressed in $\mu \mathrm{M}$ in supplementary material (Table S1).

Table 2. Concentration in equivalent $\mathrm{mM}$ of total $\mathrm{NO}$ added in dry-cured fermented sausages.

\begin{tabular}{|c|c|c|c|c|}
\hline & $0 \mathrm{NO}_{2} / \mathrm{NO}_{3}$ & $80 \mathrm{NO}_{2} / \mathrm{NO}_{3}$ & $200 \mathrm{NO}_{3}$ & $120 \mathrm{NO}_{2} / \mathrm{NO}_{3}$ \\
\hline Dose $\mathrm{NaNO}_{2}(\mathrm{ppm})$ & 0 & 80 & 0 & 120 \\
\hline Dose $\mathrm{NaNO}_{3}(\mathrm{ppm})$ & 0 & 80 & 200 & 120 \\
\hline $\begin{array}{l}\text { Concentration of total } \\
\text { NO added }(\mathrm{mM})\end{array}$ & 0 & 3 & 3.2 & 4.5 \\
\hline
\end{tabular}

After being stuffed into natural pork casings with a diameter of between 55 and $60 \mathrm{~mm}$ and having previously undergone desalting, acid treatment and rinsing. Fresh sausages were dipped into a commercial Penicillium nalgiovensis spore solution (BiovitecTexel, Dupont Danisco, France) and hung vertically in a temperature-controlled incubator to carry on the ripening process. The temperature was increased to $24{ }^{\circ} \mathrm{C}$ within $6 \mathrm{~h}$, then kept stable for one day and a half. Then, during the drying-ageing period, the temperature was maintained at $13{ }^{\circ} \mathrm{C}$ until the dry sausages reached $41 \%$ weight loss, corresponding to four weeks. The samples were frozen and stored at $-80^{\circ} \mathrm{C}$ until analysis.

\subsection{Biochemical Characterization}

\subsubsection{Determination of Nitrite and Nitrate Content}

Nitrite and nitrate were extracted according to the method of Bonifacie et al. [18]. Briefly, the deprotenization of the extract was performed by centrifugation with a Vivaspin ${ }^{\circledR}$ 2 system with a $5 \mathrm{kDa}$ cut-off threshold $\left(16^{\circ} \mathrm{C}, 900 \times \mathrm{g}\right.$ for $75 \mathrm{~min}$ with an SL 40R centrifuge from Thermo Scientific, Waltham, MA, USA) and the filtrates were used for assays.

Nitrite and nitrate ion contents were then determined using the Griess reaction with a Sigma-Aldrich colorimetric assay kit. Residual nitrite and nitrate were expressed in $\mathrm{mg} / \mathrm{kg}$ of final product (ppm).

\subsubsection{Determination of Nitrosothiol Content}

Nitrosothiol contents were determined according to Bonifacie et al. [18]. Briefly, filtrates prepared in Section 2.3.1 were saturated with $\mathrm{HgCl}_{2}$ to specifically cleave the S-NO bonds of nitrosothiols [19]. Nitrite ion contents were measured using the Griess reaction and the difference between this measure and the level of nitrite ions initially present in the sample (Section 2.3.1) gave the nitrosothiol content [19]. Nitrosothiols were expressed in $\mathrm{mg} \mathrm{S-NO/kg} \mathrm{of} \mathrm{final} \mathrm{product} \mathrm{(ppm).}$

\subsubsection{Determination of Non-Volatile Nitrosamine Content}

Non-volatile nitrosamine content was determined by the method previously described by Bonifacie et al. [18]. Filtrates prepared in Section 2.3.1 were irradiated with a UV lamp, leading to the cleavage of both S-NO bonds of nitrosothiols and N-NO bonds of nitrosamines into nitrite and nitrate.

This measure gave the sum of nitrosothiol and non-volatile nitrosamine contents. The subtraction of nitrosothiol content, obtained as described in Section 2.3.2, gave the non-volatile nitrosamines that were expressed in $\mathrm{mg} \mathrm{N}-\mathrm{NO} / \mathrm{kg}$ of meat (ppm).

\subsubsection{Evaluation of Free Iron Content}

The free iron content was measured by the ferrozine assay according to Stolze et al. [20], with slight modifications to adapt to the cured meat samples [21]. The results were expressed in $\mu \mathrm{M}$ of total free iron content. 


\subsubsection{Determination of Heme Iron Nitrosylation}

Nitrosylheme and the total heme iron content were estimated according to Hornsey [22]. The nitrosylation of heme iron was expressed as the percentage of nitrosylheme to total heme iron.

\subsubsection{Lipid Oxidation Measurement}

Lipid extraction was performed using the procedure of Folch et al. [23] with slight modifications according to Bonifacie et al. [21]. Lipid oxidation was measured by the thiobarbituric acid reactive substances (TBARS) method according to Mercier et al. [24]. The results of lipid oxidation were then expressed as $\mu \mathrm{g}$ of malondialdehyde (MDA) equivalent per $\mathrm{g}$ of lipids.

\subsubsection{Protein Oxidation Measurement}

Protein oxidation was measured by estimating the carbonyl groups using the method of Oliver et al. [25] with slight modifications [24]. Carbonyl groups were detected by reactivity with 2,4 dinitrophenylhydrazine (DNPH) to form protein hydrazones. Absorbance was measured on a Multiskan spectrum from Thermo Scientific (Waltham, MA, USA). The results were expressed as nanomoles of DNPH fixed per milligram of protein.

Protein oxidation was also evaluated by the free thiol content. Free thiols were measured by a modification of Ellman's method using 2,2'-dithiobis (5-nitropyridine) (DTNP) [26]. The results were expressed as nanomoles of DTNP bound per milligram of protein.

\subsubsection{Proteolysis Index Measurement}

The proteolysis index was estimated by the fluorescamine method according to Harkouss et al. [27]. This method is based on specific fluorescamine labeling of $\mathrm{N}$-terminal $\alpha$-amino groups of peptides and free amino acids. The fluorescence measurements were performed on a Jasco FP-8300 spectrofluorometer, (Jasco, Oklahoma City, OK, USA). The index of proteolysis was expressed in $\mu$ moles of peptides equivalent glycine by protein concentration in $\mathrm{mg}$.

\subsection{Statistical Analysis}

The statistical analysis was carried out with STATISTICA software (version 13.3) from TIBCO Software Inc. (Palo Alto, CA, USA). The values for each experimental condition were reported as the mean \pm standard error of the mean (SEM) of six independent repetitions. The effect of nitrite/nitrate treatment on the dry-cured fermented sausages was assessed by a one-way analysis of variance (ANOVA): $\left(0 \mathrm{NO}_{2} / \mathrm{NO}_{3} ; 80 \mathrm{NO}_{2} / \mathrm{NO}_{3}\right.$; $200 \mathrm{NO}_{3} ; 120 \mathrm{NO}_{2} / \mathrm{NO}_{3}$ ). The correlation matrix and ANOVA was performed using a confidence level of $1 \%$, and the post hoc test used was the Tukey test.

\section{Results and Discussion}

The modulation of the dose-response relationship of sodium nitrite and/or sodium nitrate added in dry-cured fermented sausages was evaluated through the formation of nitroso compounds and their precursors and catalysts. The chemical reactivity of NOCs in dry cured fermented sausages will also be discussed.

\subsection{Impact of Sodium Nitrite/Nitrate Added to Residual Nitrite and Nitrate}

The residual nitrite and nitrate level is a key contributor to the chemical reactivity of NOCs because of their role as precursors and their chemical conversion capability. Overall, with no addition of $\mathrm{NO}_{2} / \mathrm{NO}_{3}$, less than $5 \mathrm{ppm}$ of residual nitrate and $0.2 \mathrm{ppm}$ of nitrite was observed (Figure 2). The level of nitrate in $0 \mathrm{NO}_{2} / \mathrm{NO}_{3}$ condition is due to the presence of natural residual nitrate in meat, from 10 and $15 \mathrm{ppm}$ in fresh pork meat [28]. Moreover, protein oxidation during the curing process can lead to the production of ammonium that is 
converted into nitrite by ammonia-oxidizing bacteria and then to nitrate by nitrite-oxidizing bacteria [29-31].

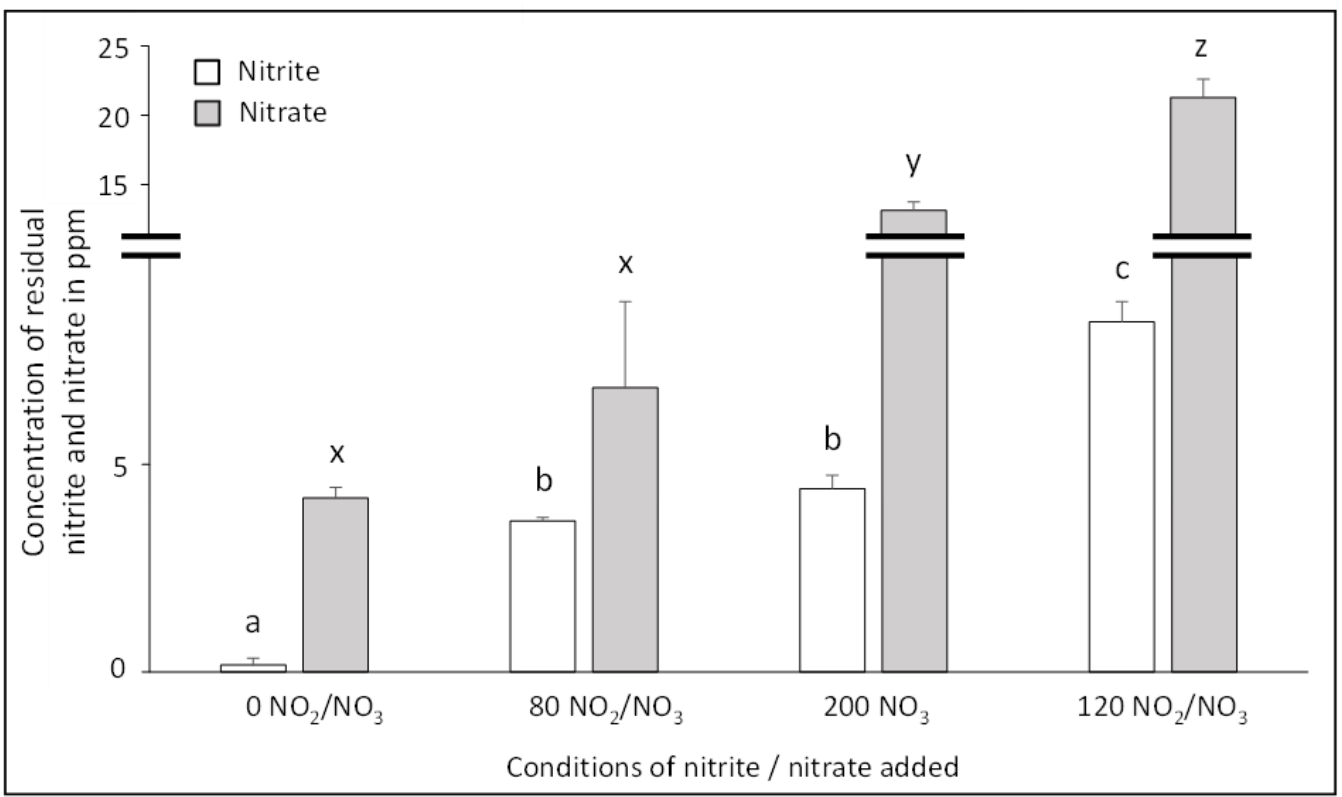

Figure 2. Effect of added doses of sodium nitrite and nitrate on the concentration of residual nitrite and residual nitrate in the cured and dry-cured fermented sausages. The rates of residual nitrite (in white) and residual nitrate (in grey) are expressed in ppm. Values are mean \pm SEM of 6 independent determinations. Values without common superscripts, a, b, c for nitrite and $\mathrm{x}, \mathrm{y}, \mathrm{z}$ for nitrate, differ significantly $(p<0.01)$.

Then, increasing the added dose led to a significant increase of residual nitrite and nitrate $(p<0.01)$. The addition of $80 \mathrm{ppm}$ of sodium nitrite and $80 \mathrm{ppm}$ sodium nitrate, corresponding to a total addition of $3 \mathrm{mM}$ of NO significantly increased $(p<0.01)$ the level of residual nitrite but not the residual nitrate. Residual nitrite was observed even when only nitrate was added (200 ppm $\mathrm{NO}_{3}$, corresponding to $3.2 \mathrm{mM}$ of added NO). The partial reduction of nitrate into nitrite, done by bacterial flora like Staphylococcus carnosum and Staphylococcus xylosus, used in the fermentation process, explains the nitrite content when only nitrate was added [2,3]. Bacterial flora, naturally present in meat or through the addition of microorganisms as starter cultures, express nitrate-reducing activity $[13,14]$. However, the process of reducing nitrates takes time and this conversion depends on the concentration of the reactants [32], among other things. For the same quantity of nitrate added initially, Christieans et al. [3] reported a similar residual nitrite content in French dry-cured fermented sausages after 34 days storage.

The $120 \mathrm{NO}_{2} / \mathrm{NO}_{3}$ condition, corresponding to the maximum $\mathrm{NO}$ added in our study $(4.5 \mathrm{mM})$, led to $21 \mathrm{ppm}$ residual nitrate and $8 \mathrm{ppm}$ residual nitrite. Sallan et al. [33] reported a residual amount of nitrite in dry fermented sausages of $12 \mathrm{ppm}$ (residual nitrate was not evaluated) for $150 \mathrm{ppm}$ nitrite added initially, i.e., $3.3 \mathrm{mM}$ equivalent of added NO. This value is half that observed in our samples because the sum of the NO added was higher. In conclusion, regardless of whether $\mathrm{NO}$ was added through $\mathrm{NO}_{2}$ and $/$ or $\mathrm{NO}_{3}$, our results demonstrated a constant increase of residual nitrate and nitrite with the molar concentration of added NO.

\subsection{Impact of Sodium Nitrite/Nitrate Added to Free and Heme Iron}

Total free iron (Figure 3A) is implicated in the chemistry of NOCs by catalyzing their formation and that of oxidation products [34]. Total heme iron and nitrosylated-heme iron were quantified and the percentage of nitrosylation was calculated (Figure 3B). We must mention that in the dry-cured fermented sausages, the sum of free and heme iron content 
led to approximately the same values, i.e., $0.25 \mathrm{mM}$, for each condition studied, whatever the concentration of $\mathrm{NO}$ added.

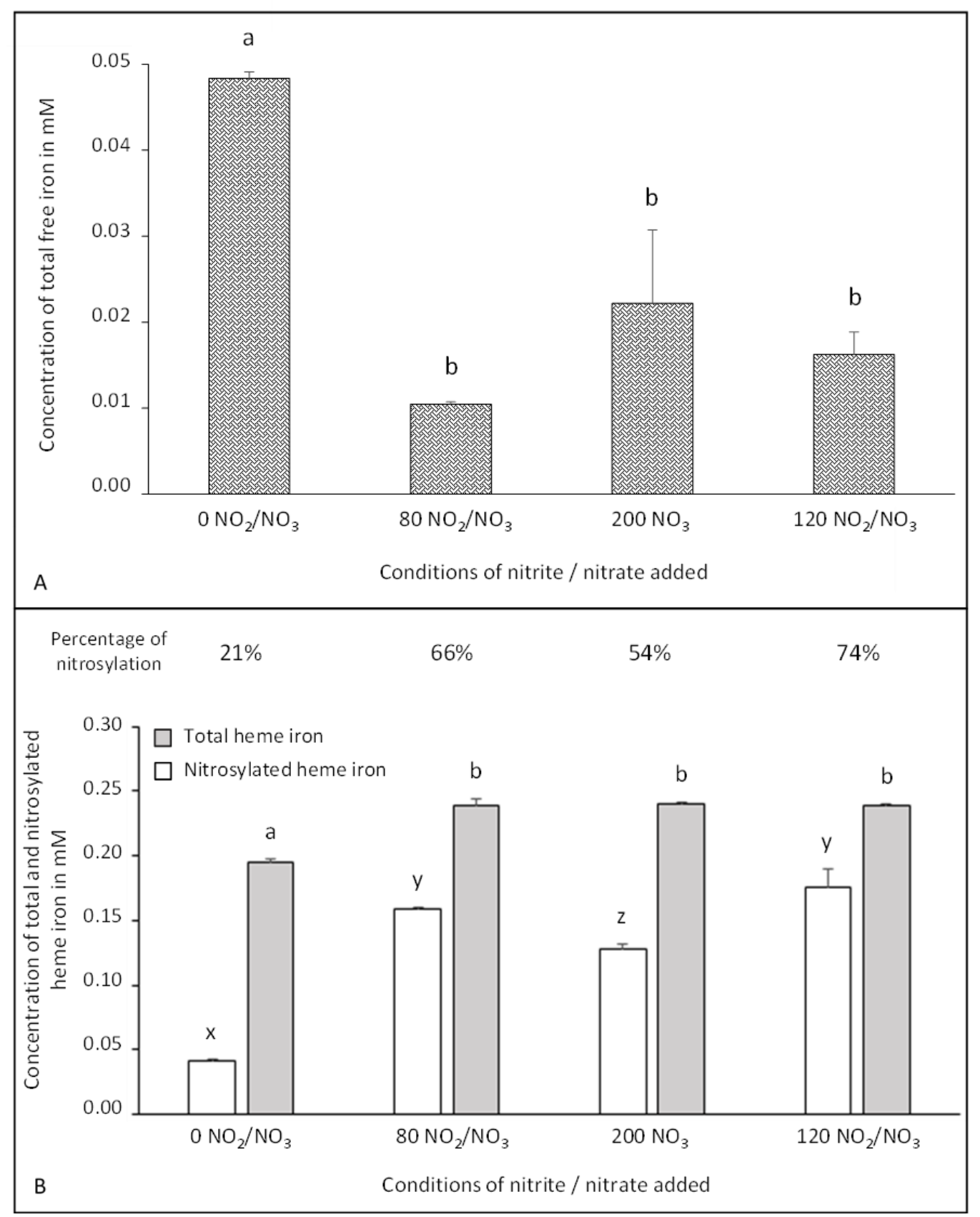

Figure 3. Effect of added doses of sodium nitrite and nitrate on the concentration of total free iron (A), nitrosylated heme iron and total heme iron (B) in dry-cured fermented sausages. The level of free iron, nitrosylated heme iron (in white) and total heme iron (in grey) are expressed in mM. Values are mean \pm SEM of 6 independent determinations. Values without common superscripts, $a, b$ for total free and heme iron and $\mathrm{x}, \mathrm{y}, \mathrm{z}$ for nitrosylated heme iron, differ significantly $(p<0.01)$.

The free iron level was significantly $(p<0.01)$ higher in the absence of nitrite/nitrate. This result can be explained by a higher release of iron from myoglobin. Moreover, the oxidative process and free radical chemistry can affect the level of free iron. Indeed, nitric oxide can neutralize superoxide radicals by the formation of peroxynitrite $\left(\mathrm{ONOO}^{-}\right)$, thereby preventing the formation of $\mathrm{H}_{2} \mathrm{O}_{2}$ involved in heme iron release [34]. The dose of added nitrite/nitrate had no effect on the total free iron content. 
In the $0 \mathrm{NO}_{2} / \mathrm{NO}_{3}$ condition, the content of total heme iron was significantly $(p<0.01)$ lower than that observed in samples with added nitrite/nitrate, regardless of the concentration. The protective effect of nitrite against the oxidative process involving the heme iron released might explain this result, as mentioned above. We hypothesize that this result was because nitrosylheme is more stable than heme iron, already described in cooked ham [21]. This hypothesis was confirmed by a negative correlation $(-0.67)$ between nitrosylheme and free iron $(p<0.001)$ (Table S2). Indeed, during oxidative stress, the release of iron from the porphyrin ring is inhibited by its nitrosylation [35]. However, when comparing curing/drying and curing/cooking processes, $35 \%$ less iron is released from myoglobin in the drying process than in the cooking one [21]. In dry products, nitrosomyoglobin stays in its native form, while in cooked products, heat modifies the protein part of the heme pocket leading to a nitroso-hemochrome. Myoglobin denaturation under heating may reduce the stability of heme iron [36].

The basal nitrosylation of $21 \%$ observed in the $0 \mathrm{NO}_{2} / \mathrm{NO}_{3}$ condition may be due to the residual nitrate present in meat that was partially reduced into nitrite during sausage aging [31], as described in Section 3.1. This basal rate of nitrosylation shows the importance of studying the residual contents of nitrite/nitrate in products in which they are not added through sodium $\mathrm{NO}_{2} / \mathrm{NO}_{3}$. In addition, this result supports the hypothesis of basal nitrosylation due to the nitrate reductase activity of the bacterial flora in the dry cured fermented sausages.

Adding nitrite/nitrate significantly increased $(p<0.01)$ the percentage of nitrosylation up to $74 \%$ for the $120 \mathrm{NO}_{2} / \mathrm{NO}_{3}$ condition, corresponding to $4.5 \mathrm{mM}$ equivalent of added NO. A significant increase in nitroso-myoglobin was also observed with the addition of $\mathrm{NO}_{2} / \mathrm{NO}_{3}$ in dry cured loins [37] and a percentage of nitrosylation of $66 \%$ was observed in traditional Spanish dry fermented sausages with $4.35 \mathrm{mM}$ equivalent of $\mathrm{NO}$ added [38].

In conclusion, starter cultures and their nitrate reductase activity can lead to the formation of nitrosylheme even without added sodium $\mathrm{NO}_{2} / \mathrm{NO}_{3}$. Moreover, the addition of sodium nitrite/nitrate reduces the oxidative process leading to the release of iron from myoglobin.

\subsection{Impact of Sodium Nitrite/Nitrate Added on Nitrosation Reactions}

The products of nitrosation, i.e., nitrosothiols and nitrosamines were measured in dry-cured fermented sausages (Figure 4). The nitrosothiol level did not differ significantly, whatever the dose of sodium nitrite/nitrate. No nitrosamine was detected at 0 or $80 \mathrm{NO}_{2} / \mathrm{NO}_{3}$; they were detected only for the two highest conditions of added sodium nitrite/nitrate, i.e., $120 \mathrm{NO}_{2} / \mathrm{NO}_{3}$ and $200 \mathrm{NO}_{3}$.

The literature on nitrosation in dry-cured fermented sausages is scarce and, to our knowledge, there are no studies showing the impact of nitrite and nitrate levels on the amount of nitrosothiols and total non-volatile nitrosamines in these products. Nonetheless, one study quantified the levels of five individual non-volatile nitrosamines in salami [39]. The sum of these five nitrosamines was evaluated at $2 \mathrm{ppm}$, much lower than our results, but the total non-volatile nitrosamine level was not considered. In addition, the aging duration of these products was not reported; a shorter curing time may explain the lower rate of nitrosamines formed compared to those we observed. Indeed, the proteolysis reaction occurring during the curing process promotes the cleavage of peptidyl chains by proteases, thus possibly promoting protein nitrosation. Moreover, the levels of nitrite and/or nitrate added in Danish salami were not specified, so it is difficult to conclude without more information.

The absence of ascorbate added in dry-cured fermented sausages can also explain our results. Indeed, no non-volatile nitrosamines were detected in a cooked meat model with ascorbate, regardless of the concentration of added nitrite [21]. In this product, the addition of ascorbate favored the formation of nitric oxide $\left(\mathrm{NO}^{\circ}\right)$, which is a less effective nitrosating agent than nitrosonium ions $\left(\mathrm{NO}^{+}\right)$formed in low $\mathrm{pH}$ conditions and in the absence of a reducing agent such ascorbate. Moreover, in this cooked product, the highest 
concentration of added sodium nitrite was lower $(1.9 \mathrm{mM})$ than in dry-cured fermented sausages $(4.5 \mathrm{mM})$.

In conclusion, the formation of non-volatiles nitrosamines was modulated by increasing the sodium $\mathrm{NO}_{2} / \mathrm{NO}_{3}$ concentration. Indeed, these nitroso-compounds were formed only above a concentration of $3 \mathrm{mM}$ of total $\mathrm{NO}$ added $\left(80 \mathrm{NO}_{2} / \mathrm{NO}_{3}\right)$.

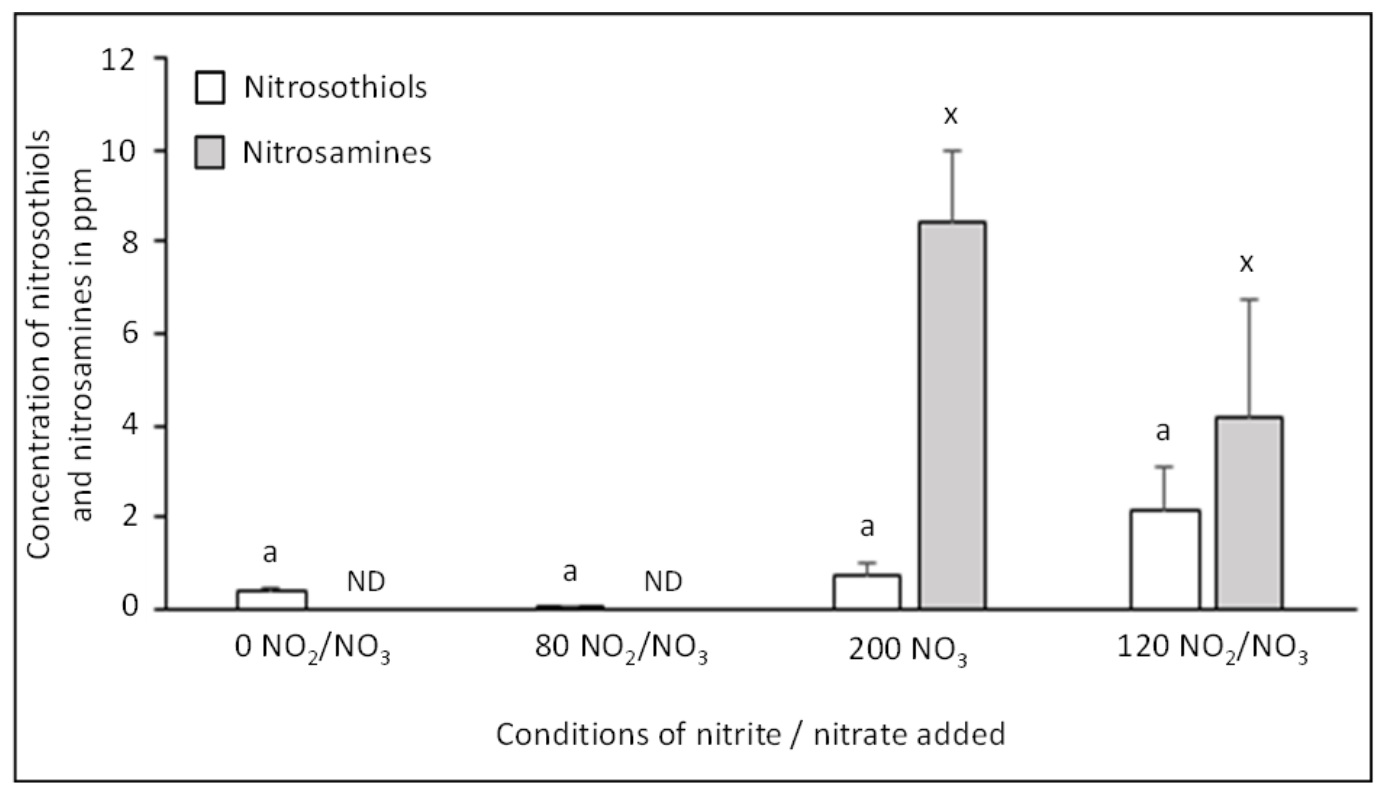

Figure 4. Effect of added doses of sodium nitrite and nitrate on the concentration of nitrosation products, nitrosothiols and nitrosamines, in dry-cured fermented sausages. The level of nitrosothiols (in white) and nitrosamines (in grey) are expressed in ppm Values are mean \pm SEM of 6 independent determinations. Values without common superscripts, a for nitrosothiols and $x$ for nitrosamines, differ significantly $(p<0.01)$. ND $=$ not detected.

\subsection{Impact of Sodium Nitrite/Nitrate Added to Lipid and Protein Oxidation}

Lipid oxidation was evaluated in dry-cured fermented sausages by the TBARS test (Table 3) which measures the level of aldehydes, final oxidation products, with among others dialdehydes and 4-hydroxy-2-nonenal (HNE) (Figure 5, Reaction (3)). Values ranged from 6 to $13 \mu \mathrm{g}$ of MDA equivalent per g of lipids. Lipid oxidation was significantly $(p<0.01)$ lower with added sodium $\mathrm{NO}_{2} / \mathrm{NO}_{3}$, whatever the dose, confirming the powerful antioxidant capability of nitrite. These results are in line with those reported in dry-cured loins with several added doses of nitrite/nitrate, from 0 to $150 \mathrm{ppm}$ [37]. Moreover, as described in Section 3.2., in the absence of added sodium $\mathrm{NO}_{2} / \mathrm{NO}_{3}$, the free iron concentration was higher. Free iron is known to promote lipid oxidation by the Fenton reaction, leading to the formation of free radicals [34]. These mechanisms were strengthened by the positive correlation $(0.68)(p<0.001)$ between the free iron and TBARS (Table S2). Moreover, nitric oxide ends the oxidation reactions by reacting with lipoperoxide radicals $\mathrm{L}(\mathrm{O}) \mathrm{O}^{\circ}$ to form peroxynitrite derivatives $\mathrm{L}(\mathrm{O}) \mathrm{ONO}$ and more stable lipid nitro-compound derivatives $\mathrm{LONO}_{2}$ [40] (Reaction (1), Figure 5). This reaction prevented the formation of aldehydes (Reaction (2), Figure 5) involved in reaction with TBA (Reaction (3), Figure 5). 
Table 3. Effect of added doses of sodium nitrite and nitrate on the concentration of thiobarbituric acid reactive substances (TBARS), carbonyl and free thiol groups in dry-cured fermented sausages.

\begin{tabular}{|c|c|c|c|c|}
\hline & $0 \mathrm{NO}_{2} / \mathrm{NO}_{3}$ & $80 \mathrm{NO}_{2} / \mathrm{NO}_{3}$ & $200 \mathrm{NO}_{3}$ & $120 \mathrm{NO}_{2} / \mathrm{NO}_{3}$ \\
\hline $\begin{array}{c}\text { TBARS } \\
\mu \mathrm{g} \text { MDA/g } \\
\text { lipids }\end{array}$ & $12.67^{\mathrm{a}} \pm 0.39$ & $7.34^{b} \pm 0.41$ & $8.39^{b} \pm 0.89$ & $6.05^{b} \pm 0.91$ \\
\hline $\begin{array}{c}\text { Carbonyl groups } \\
\text { nmoles } / \mathrm{mg} \\
\text { proteins }\end{array}$ & $2.44^{a} \pm 0.06$ & $2.74^{b} \pm 0.04$ & $2.79^{b} \pm 0.12$ & $2.79^{b} \pm 0.06$ \\
\hline $\begin{array}{c}\text { Free thiol groups } \\
\text { nmoles/mg } \\
\text { proteins }\end{array}$ & $33.72^{a} \pm 1.87$ & $32.65^{a} \pm 3.38$ & $30.68^{a} \pm 2.12$ & $26.26^{\mathrm{a}} \pm 1.66$ \\
\hline
\end{tabular}

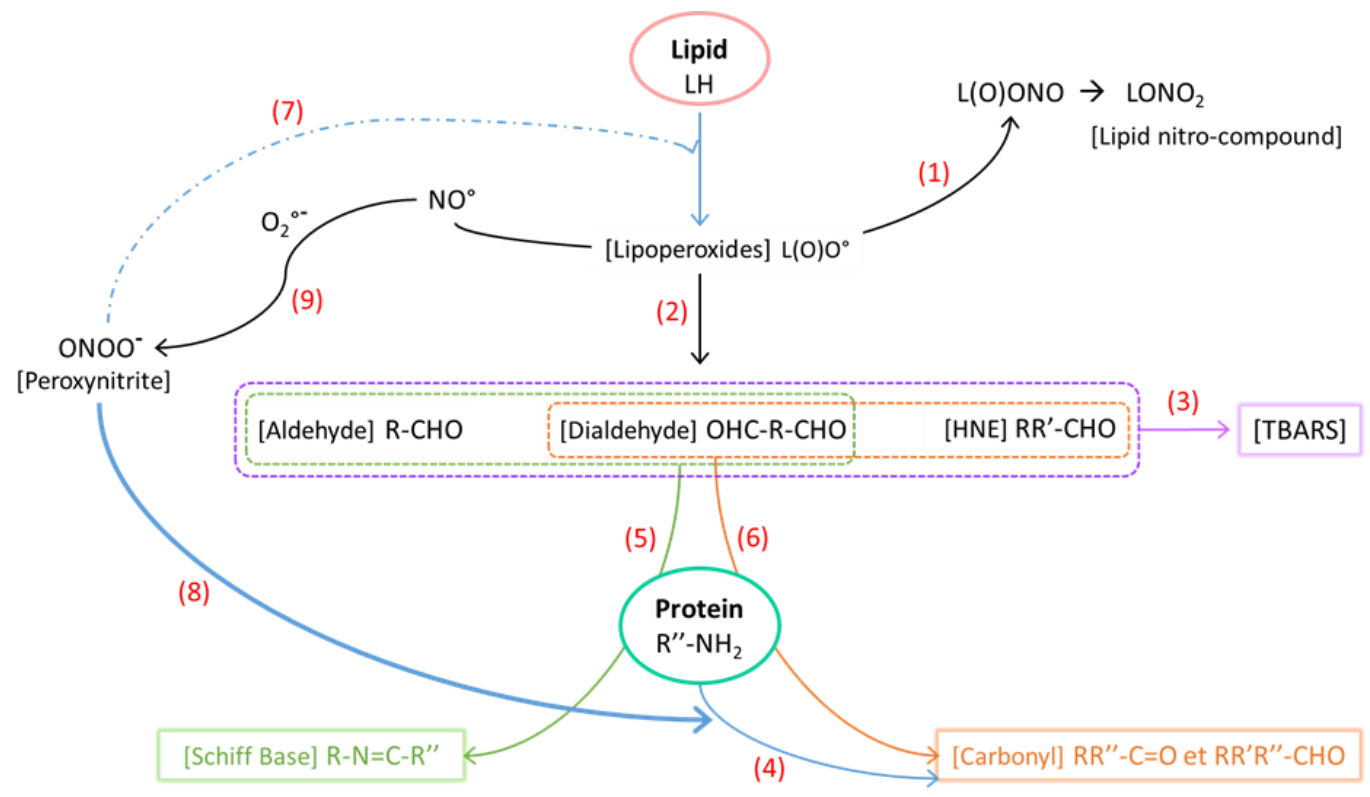

Figure 5. Reactions involved in the oxidation of lipids and proteins in dry-cured fermented sausages. The oxidation reactions are represented by blue arrows; reaction between nitric oxide and lipoperoxides: Reaction (1); formation of aldehyde from lipoperoxides: Reaction (2); formation of TBARS: Reaction (3); formation of carbonyl from protein oxidation: Reaction (4); formation of Schiff base: Reaction (5); formation of carbonyl from dialdehydes and HNE: Reaction (6); lipid oxidation by $\mathrm{ONOO}^{-}$: Reaction (7); protein oxidation by $\mathrm{ONOO}^{-}$: Reaction (8); formation of peroxynitrite $\left(\mathrm{ONOO}^{-}\right)$: Reaction (9). Reaction (8) (in bold) is favored in comparison with Reaction (7) (in dashes) because peroxynitrite oxidizes preferentially proteins more than lipids.

In dry-cured fermented sausages, increasing the dose of sodium $\mathrm{NO}_{2} / \mathrm{NO}_{3}$ did not significantly affect the level of lipid oxidation, demonstrating that the lower dose, 80 ppm of $\mathrm{NaNO}_{2}$ and 80 ppm of $\mathrm{NaNO}_{3}$, was enough to limit lipid oxidation. In dry cured-loins [37], where the process is different from dry-cured fermented sausage, a lower dose, i.e., 37.5 ppm of $\mathrm{NaNO}_{2}$ and 37.5 ppm of $\mathrm{KNO}_{3}$, was also sufficient to limit lipid oxidation and there was no effect of increasing nitrite/nitrate dose. The decrease of lipid oxidation with added nitrite, regardless of the concentration, has also been described in a cured and cooked product [21], so it appears that the involvement of free iron in the oxidation mechanisms and the antioxidant capacity of nitrite previously described thus occur independently of the curing process.

Carbonyl groups and free thiol content (Table 3) were evaluated in dry-cured fermented sausages as chemical markers of protein oxidation. 
Contrary to lipid oxidation, the amount of carbonyls was slightly higher in the presence of added sodium $\mathrm{NO}_{2} / \mathrm{NO}_{3}$, approximately $10 \%$, and this nitrite/nitrate effect was significant $(p<0.01)$. In fermented sausages, Villaverde et al. [41] observed the same increase of protein carbonyl groups, with 75 and $150 \mathrm{ppm}$ of added nitrite $(1.6$ and $3.3 \mathrm{mM}$ equivalent of total added NO, respectively). This effect tended to disappear for longer periods of conservation, longer than 50 days, but no explanation was provided.

Interactions between the oxidation of lipids and proteins [42] could explain these contrasting results between TBARS and carbonyls.

Firstly, nitrite inhibits lipid oxidation and so decreases the TBARS level by reacting with lipoperoxides, as described in reaction (1) (Figure 5). Nitrite can also interact with $\mathrm{NH} / \mathrm{NH}_{2}$ groups of basic amino acids and so interferes with protein carbonylation. Indeed, protein carbonyl groups can be generated directly by amino acid oxidation (Reaction (4), Figure 5) [43]. Nevertheless, nitrite has greater efficacy in trapping intermediates in lipid oxidation than in protein carbonylation. Indeed, at neutral $\mathrm{pH}$, the reaction of nitrite with lipoperoxide radicals exhibits a constant rate, $\mathrm{k}=2.109 \mathrm{M}^{-1} \mathrm{~s}^{-1}$ [34], well above that corresponding to amine nitrosation, $\mathrm{k}$ of the order of 105 to $106 \mathrm{M}^{-1} \mathrm{~s}^{-1}$ [44].

Secondly, the formation of Schiff bases can decrease the level of TBARS and simultaneously increase protein carbonyls (when dialdehydes are involved), as shown in reactions (5) and (6) (Figure 5). Indeed, proteins can be carbonylated indirectly by the formation of Schiff bases between free amino groups of proteins (a-terminal amino groups or e-lysine amino groups) and aldehydes (Reaction (5), Figure 5). Dialdehydes like MDA can also react with free amino groups of proteins, leading to the formation of Schiff bases (Reaction (5), Figure 5) and also to a carbonyl group with its second free aldehyde function (Reaction (6), Figure 5) [43]. The mechanisms by which nitrite could favor the formation of Schiff bases is not clear but has already been observed in fermented sausages by Villaverde et al. [41]. Protein conformational changes, due to the nitrosation (nitrosotryptophan) or nitration (nitrotryptophan and nitrotyrosine) of certain amino acids could render amino groups of proteins or peptides more accessible to hydrophobic aldehydes and so favor Schiff bases formation.

Finally, the contrasting impact of nitrite on TBARS and carbonyls could be linked to greater sensitivity of proteins than lipids to highly oxidative peroxynitrite $\left(\mathrm{ONOO}^{-}\right)$ (Reactions (7) and (8), Figure 5) which can be formed from nitrite in the presence of iron following reactions $\left(\mathrm{NO}_{2}^{-}+\mathrm{H}^{+} \leftrightarrow \mathrm{HNO}_{2}\right)$ then $\left(\mathrm{Fe}^{2+}+\mathrm{HNO}_{2} \leftrightarrow \mathrm{Fe}^{3+}+\mathrm{NO}^{\circ}+\mathrm{OH}^{-}\right)$ and $\left(\mathrm{NO}^{\circ}+\mathrm{O}_{2}{ }^{\circ-} \rightarrow \mathrm{ONOO}^{-}\right.$), (Reaction (9), Figure 5), and which is an excellent protein oxidant [45].

The free thiol content ranges from 26 to $33 \mathrm{nmol} / \mathrm{mg}$ protein, which corresponds to the values found in dry fermented sausages after 29 days [15], with a content up to $29 \mathrm{nmol} / \mathrm{mg}$ protein. Overall, there was no effect of sodium $\mathrm{NO}_{2} / \mathrm{NO}_{3}$ on the content of free thiol groups. In meat products, the level of free thiols depends on the oxidation of thiol groups, their reduction and, in the presence of a nitrite source, to their nitrosation/nitrosylation leading to nitrosothiol compounds. For example, free thiols of cysteine can be oxidized in disulfide bonds according to this reaction (2 R-SH $\rightarrow$ RS-SR), inducing a decrease of free thiols. However, this reaction can be reversed by the reduction of certain disulfide bonds by thioredoxin reductase, the main protein disulfide reductase [46]. The participation of bacterial flora in this reduction could also be considered. The presence of a nitrite source can lead to the formation of nitrosothiols by the addition of $\mathrm{NO}$ to free thiols following the reaction ( $\mathrm{R}-\mathrm{SH}+\mathrm{NO} \rightarrow \mathrm{R}-\mathrm{SNO}$ ), as discussed in Section 3.3.

As several mechanisms occur at the same time, it is difficult to assess the share and impact of each of them in the evolution of free thiol content, a chemical marker of protein oxidation that could complement the protein oxidation results initially provided by the carbonyl content.

To conclude, lipid oxidation decreased significantly with the addition of $80 \mathrm{ppm}$ sodium $\mathrm{NO}_{2} / \mathrm{NO}_{3}$, in particular due to the role of the latter in the formation of stable lipid 
nitro-compound derivatives and in the release of free iron involved in the Fenton reaction. Conversely, this addition leads to a slight increase in the amount of carbonyl groups.

\subsection{Impact of Added Sodium Nitrite/Nitrate on the Proteolysis Index}

It is important to take the proteolysis index into account in the formation of NOCs because of the release of peptides and free amino acids that might be further involved in the chemical reactivity. The proteolysis index was evaluated in dry-cured fermented sausages (Figure 6 ) and was significantly decreased $(p<0.01)$ by the addition of sodium $\mathrm{NO}_{2} / \mathrm{NO}_{3}$. This effect could be explained by the binding of $\mathrm{NO}$ to certain amino acids, thereby modifying the conformation of proteins and inhibiting optimal recognition by proteases [47]. This decrease could also be explained by the adduction of $\mathrm{NO}$ at the active site of the proteases, which would make them less effective. Indeed, in meat, cysteine proteases such as cathepsin are highly involved in proteolysis at $\mathrm{pH}$ less than or equal to 5 . As these proteases act with a cysteine group at their active site, they can lose their activity by the nitrosation of the thiol group, as already described in another model [48]. In addition, the formation of carbonyls in dry-cured fermented sausages, presented in a previous section, could also lead to difficult recognition of proteins by proteases.

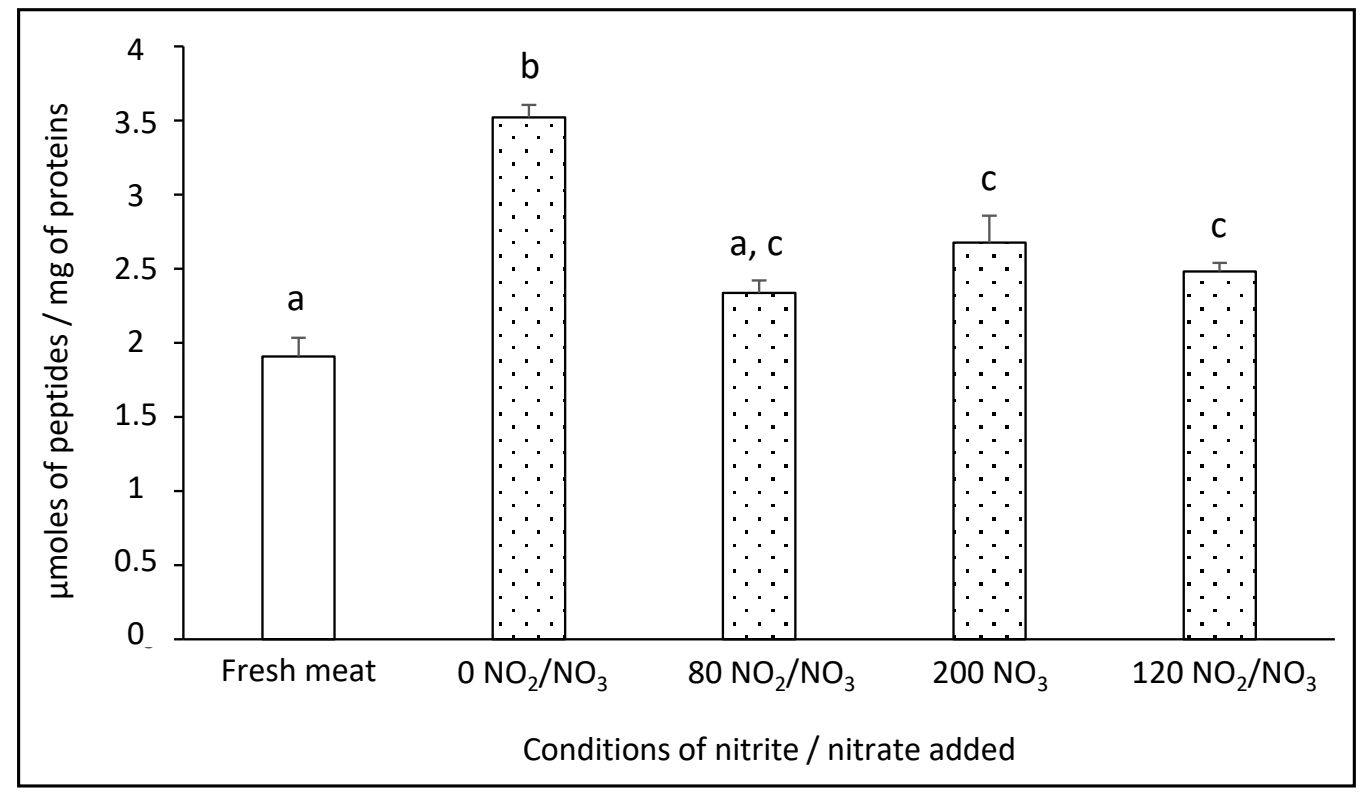

Figure 6. Effect of added doses of sodium nitrite and nitrate on the proteolysis index in dry-cured fermented sausages. The proteolysis index is expressed in $\mu$ moles of peptides $/ \mathrm{mg}$ of proteins. Values are mean \pm SEM of 6 independent determinations. Values without common superscripts, differ significantly $(p<0.01)$.

The maximum value of $3.5 \mu$ moles of peptides/mg of proteins was reached in the absence of added nitrite/nitrate, matching approximately $26 \%$ of proteolysis. The proteolysis index of $1.9 \mu$ moles of peptides in fresh meat was significantly $(p<0.01)$ lower compared to dry sausages at the end of the process in $200 \mathrm{NO}_{3}$ and $120 \mathrm{NO}_{2} / \mathrm{NO}_{3}$ conditions. The curing process promotes proteolysis as several processing conditions are involved. Indeed, meat peptides generated by the action of endogenous proteases during the ripening of dry-cured fermented sausages have been reported [49]. The addition of starter cultures is also involved in proteolysis due to their acidification capacity [49], as a decrease of $\mathrm{pH}$ promotes the activity of endogenous proteases [50]. Moreover, starter cultures like lactic acid bacteria and staphylococci, play a significant role in proteolysis during the ripening of dry-cured fermented sausages through the action of microbial enzymes, generating large amounts of peptides and free amino acids [51]. The drying-ageing stage is also reported to 
significantly increase the total free amino acid concentration in different varieties of dry fermented sausages [52].

The curing process increases the rate of proteolysis; however, the addition of sodium nitrite/nitrate decreases this content, regardless of the concentration.

\section{Conclusions}

This study gives new insights into the formation of nitroso compounds in dry-cured fermented sausages. Among the highlights, the addition of $80 \mathrm{ppm}$ of sodium nitrite and nitrate was sufficient to decrease lipid peroxidation without the formation of nitrosamines. Moreover, this concentration was also sufficient to decrease the release of free iron. This is a major result since the iron released is involved in the formation of oxidation products. Furthermore, the results showed that the use of starter cultures and the addition of sodium nitrite/nitrate promote nitrosylation. The nitrosamine content, higher in the high $\mathrm{NO}_{2} / \mathrm{NO}_{3}$ condition, stressed the importance of investigating the addition of ascorbate in dry-cured fermented sausage formulations.

This study provided new knowledge on the mechanisms of nitroso compound formation and oxidation reactions in a dry-cured fermented sausage. The next steps will be to establish the reaction pathways involved in the formation of NOCs during the digestion of cured fermented meat. Indeed, the conditions of the digestive environment, such as low gastric $\mathrm{pH}$, reducing conditions and oxygen pressure promote the formation of nitrite derivatives, such as nitric oxide and nitrosonium ions, which are involved in the formation of nitroso compounds.

Supplementary Materials: The following are available online at https://www.mdpi.com/article/ 10.3390/foods10040852/s1, Table S1: Effect of added doses of sodium nitrite and nitrate on the concentration of residual nitrite, residual nitrate, nitrosothiols and nitrosamines in dry-cured fermented sausages. The concentrations of their components are expressed in $\mu \mathrm{M}$. Values are mean of 6 independent determinations. Values without common superscripts, a, b, c for nitrite, $\mathrm{x}, \mathrm{y}, \mathrm{z}$ for nitrate, $\alpha$ for nitrosothiols and $\beta$ for nitrosamines differ significantly $(p<0.01)$. ND for not detected. Table S2: Molecular interactions in dry-cured fermented sausages studied using a correlation matrix.

Author Contributions: A.B., conceptualization, validation, formal analysis, investigation, data curation, writing; P.G., conceptualization, validation, formal analysis, investigation, data curation, writing, supervision, project administration, funding acquisition; A.P., conceptualization, validation, investigation, data curation, writing, supervision, project administration, funding acquisition; G.N., conceptualization, validation, investigation, data curation, writing, supervision, project administration, funding acquisition; L.P., validation, investigation, data curation, writing; V.S., validation, investigation, data curation, writing; V.S.-L., conceptualization, validation, formal analysis, investigation, data curation, writing, supervision, project administration, funding acquisition; L.T., conceptualization, validation, formal analysis, investigation, data curation, writing, supervision, project administration. All authors have read and agreed to the published version of the manuscript.

Funding: This research was funded by INRAE and the consortium ADDUITS.

Institutional Review Board Statement: Not applicable.

Informed Consent Statement: Not applicable.

Data Availability Statement: The data presented in this study are available on request from the corresponding author.

Acknowledgments: We thank Laurent Aubry, Claude Ferreira, Elsa Laurent, and Jacques Rouel for their technical contribution to this paper. The authors would also like to thank Martine Carlier and Jean Luc Martin for their scientific contributions.

Conflicts of Interest: Aurélie Promeyrat and Gilles Nassy were employed by the Institut Français du Porc (IFIP). Aline Bonifacie is co-affiliated with the Institut Français du Porc (IFIP) and INRAE. Philippe Gatellier, Laurent Picgirard, Valérie Scislowski, Véronique Santé-Lhoutellier and Laëtitia Théron declare no conflict of interest. 


\section{References}

1. Hébel, P. La consommation de charcuteries en France. Cah. Nutr. Diététique 2019, 54, 5S16-5S22. [CrossRef]

2. Hammes, W.P. Metabolism of nitrate in fermented meats: The characteristic feature of a specific group of fermented foods. Food Microbiol. 2012, 29, 151-156. [CrossRef] [PubMed]

3. Christieans, S.; Picgirard, L.; Parafita, E.; Lebert, A.; Gregori, T. Impact of reducing nitrate/nitrite levels on the behavior of Salmonella Typhimurium and Listeria monocytogenes in French dry fermented sausages. Meat Sci. 2018, 137, 160-167. [CrossRef] [PubMed]

4. Lebrun, S.; Van Nieuwenhuysen, T.; Crèvecoeur, S.; Vanleyssem, R.; Thimister, J.; Denayer, S.; Jeuge, S.; Daube, G.; Clinquart, A.; Fremaux, B. Influence of reduced levels or suppression of sodium nitrite on the outgrowth and toxinogenesis of psychrotrophic Clostridium botulinum Group II type B in cooked ham. Int. J. Food Microbiol. 2020, 334, 108853. [CrossRef]

5. Berardo, A.; De Maere, H.; Stavropoulou, D.; Rysman, T.; Leroy, F.; De Smet, S. Effect of sodium ascorbate and sodium nitrite on protein and lipid oxidation in dry fermented sausages. Meat Sci. 2016, 121, 359-364. [CrossRef]

6. Sottero, B.; Leonarduzzi, G.; Testa, G.; Gargiulo, S.; Poli, G.; Biasi, F. Lipid Oxidation Derived Aldehydes and Oxysterols Between Health and Disease. Eur. J. Lipid Sci. Technol. 2019, 121, 1700047. [CrossRef]

7. Honikel, K.-O. The use and control of nitrate and nitrite for the processing of meat products. Meat Sci. 2008, 78, 68-76. [CrossRef]

8. De Mey, E.; De Maere, H.; Paelinck, H.; Fraeye, I. VolatileN-nitrosamines in meat products: Potential precursors, influence of processing, and mitigation strategies. Crit. Rev. Food Sci. Nutr. 2017, 57, 2909-2923. [CrossRef]

9. Tricker, A.R.; Preussmann, R. Carcinogenic N-nitrosamines in the diet: Occurrence, formation, mechanisms and carcinogenic potential Mutat. Res. Genet. Toxicol. 1991, 259, 277-289. [CrossRef]

10. Kuhnle, G.G.C.; Bingham, S.A. Dietary meat, endogenous nitrosation and colorectal cancer. Biochem. Soc. Trans. 2007, 35, 1355-1357. [CrossRef] [PubMed]

11. Kostka, T.; Fohrer, J.; Guigas, C.; Briviba, K.; Seiwert, N.; Fahrer, J.; Steinberg, P.; Empl, M.T. Synthesis and in vitro characterization of the genotoxic, mutagenic and cell-transforming potential of nitrosylated heme. Arch. Toxicol. 2020, 94, 3911-3927. [CrossRef]

12. Institut du Porc. Code des Usages de la Charcuterie, de la Salaison et des Conserves de Viande. Available online: https: / / www.ifip.asso.fr/fr/content/code-des-usages-de-la-charcuterie-de-la-salaison-et-des-conserves-de-viandes (accessed on 14 April 2017).

13. Majou, D.; Christieans, S. Mechanisms of the bactericidal effects of nitrate and nitrite in cured meats. Meat Sci. 2018, 145, 273-284. [CrossRef]

14. Perea-Sanz, L.; Montero, R.; Belloch, C.; Flores, M. Nitrate reduction in the fermentation process of salt reduced dry sausages: Impact on microbial and physicochemical parameters and aroma profile. Int. J. Food Microbiol. 2018, 282, 84-91. [CrossRef]

15. Safa, H.; Gatellier, P.; Lebert, A.; Picgirard, L.; Mirade, P.-S. Effect of Combined Salt and Animal Fat Reductions on Physicochemical and Biochemical Changes During the Manufacture of Dry-Fermented Sausages. Food Bioprocess Technol. 2015, 8, $2109-2122$. [CrossRef]

16. Toldra, F. Proteolysis and lipolysis in flavour development of dry-cured meat products. Meat Sci. 1998, 49, 101-110. [CrossRef]

17. Suntsova, T.P.; Beda, N.V.; Nedospasov, A.A. Structural features of proteins responsible for resistanceof tryptophan residues to nitrosylation. IUBMB Life 2002, 54, 281-292. [CrossRef] [PubMed]

18. Bonifacie, A.; Aubry, L.; Gatellier, P.; Santé-Lhoutellier, V.; Théron, L. Determination of nitroso-compounds in food products. MethodsX 2021, 8, 101289. [CrossRef]

19. Gaston, B. Nitric oxide and thiol groups. Biochim. Biophys. Acta 1999, 1411, 323-333. [CrossRef]

20. Stolze, K.; Dadak, A.; Liu, Y.; Nohl, H. Hydroxylamine and phenol-induced formation of methemoglobin and free radical intermediates in erythrocytes. Biochem. Pharmacol. 1996, 52, 1821-1829. [CrossRef]

21. Bonifacie, A.; Promeyrat, A.; Nassy, G.; Gatellier, P.; Santé-Lhoutellier, V.; Théron, L. Chemical reactivity of nitrite and ascorbate in a cured and cooked meat model implication in nitrosation, nitrosylation and oxidation. Food Chem. 2021, 348, 129073. [CrossRef]

22. Hornsey, H.C. The colour of cooked cured pork-Estimation of the Nitric oxide-Haem Pigments. J. Sci. Food Agric. 1956, 7, 534-540. [CrossRef]

23. Folch, J.; Lees, M.; Sloane-Stanley, G.H. A simple method for the isolation and purification of total lipides from animal tissues. J. Biol. Chem. 1957, 226, 497-509. [CrossRef]

24. Mercier, Y.; Gatellier, P.; Viau, M.; Remignon, H.; Renerre, M. Effect of dietary fat and vitamin E on colour stability and on lipid and protein oxidation in Turkey meat during storage. Meat Sci. 1998, 48, 301-318. [CrossRef]

25. Oliver, C.N.; Ahn, B.; Moermant, E.J.; Goldstein, S.; Stadtman, E.R. Age-related changes in oxidized proteins. J. Biol. Chem. 1987, 262, 5488-5491. [CrossRef]

26. Morzel, M.; Gatellier, P.; Sayd, T.; Renerre, M.; Laville, E. Chemical oxidation decreases proteolytic susceptibility of skeletal muscle myofibrillar proteins. Meat Sci. 2006, 73, 536-543. [CrossRef]

27. Harkouss, R.; Mirade, P.-S.; Gatellier, P. Development of a rapid, specific and efficient procedure for the determination of proteolytic activity in dry-cured ham: Definition of a new proteolysis index. Meat Sci. 2012, 92, 84-88. [CrossRef] [PubMed]

28. Iammarino, M.; Di Taranto, A. Nitrite and nitrate in fresh meats: A contribution to the estimation of admissible maximum limits to introduce in directive 95/2/EC. Int. J. Food Sci. Technol. 2012, 47, 1852-1858. [CrossRef] 
29. Laloo, A.E.E.; Wei, J.; Wang, D.; Narayanasamy, S.; Van Wonterghem, I.; Waite, D.; Steen, J.; Kaysen, A.; Heintz-Buschart, A.; Wang, Q.; et al. Mechanisms of Persistence of the Ammonia-Oxidizing BacteriaNitrosomonasto the Biocide Free Nitrous Acid. Environ. Sci. Technol. 2018, 52, 5386-5397. [CrossRef] [PubMed]

30. Stein, L.Y. Insights into the physiology of ammonia-oxidizing microorganisms. Curr. Opin. Chem. Biol. 2019, 49, 9-15. [CrossRef]

31. Marco, A.; Navarro, J.L.; Flores, M. The influence of nitrite and nitrate on microbial, chemical and sensory parameters of slow dry fermented sausage. Meat Sci. 2006, 73, 660-673. [CrossRef]

32. Sebranek, J.G.; Bacus, J.N. Cured meat products without direct addition of nitrate or nitrite: What are the issues? Meat Sci. 2007, 77, 136-147. [CrossRef] [PubMed]

33. Sallan, S.; Kaban, G.; Kaya, M. Nitrosamines in sucuk: Effects of black pepper, sodium ascorbate and cooking level. Food Chem. 2019, 288, 341-346. [CrossRef]

34. Bechaux, J.; De La Pomélie, D.; Theron, L.; Santé-Lhoutellier, V.; Gatellier, P. Iron-catalysed chemistry in the gastrointestinal tract: Mechanisms, kinetics and consequences. A review. Food Chem. 2018, 268, 27-39. [CrossRef] [PubMed]

35. Juckett, M.; Zheng, Y.; Yuan, H.; Pastor, T.; Antholine, W.; Weber, M.; Vercelloti, G. Heme and the endothelium-effects of nitric oxide on catalytic iron and heme degradation by heme oxygenase. J. Biol. Chem. 1998, 273, 23388-23397. [CrossRef] [PubMed]

36. Purchas, R.W.; Simcock, D.C.; Knight, T.W.; Wilkinson, B.H.P. Variation in the form of iron in beef and lamb meat and losses of iron during cooking and storage. Int. J. Food Sci. Technol. 2003, 38, 827-837. [CrossRef]

37. Higuero, N.; Moreno, I.; Lavado, G.; Vidal-Aragón, M.C.; Cava, R. Reduction of nitrate and nitrite in Iberian dry cured loins and its effects during drying process. Meat Sci. 2020, 163, 108062. [CrossRef]

38. Ibañez, C.; Quintanilla, L.; Cid, C.; Astiasarán, I.; Bello, J. Dry fermented sausages elaborated with Lactobacillus plantarumStaphylococcus carnosus part I: Effect of partial replacement of $\mathrm{NaCl}$ with $\mathrm{KCl}$ on the stability and the nitrosation process. Meat Sci. 1996, 44, 227-234. [CrossRef]

39. Herrmann, S.S.; Duedahl-Olesen, L.; Granby, K. Occurrence of volatile and non-volatile N-nitrosamines in processed meat products and the role of heat treatment. Food Control. 2015, 48, 163-169. [CrossRef]

40. Rubbo, H.; Batthyany, C.; Radi, R. Nitric Oxide: Oxygen Radical Interactions in Atherosclerosis. Biol. Res. 2000, 33, 167-175. [CrossRef] [PubMed]

41. Villaverde, A.; Morcuende, D.; Estévez, M. Effect of Curing Agents on the Oxidative and Nitrosative Damage to Meat Proteins during Processing of Fermented Sausages. J. Food Sci. 2014, 79, C1331-C1342. [CrossRef] [PubMed]

42. Estévez, M. Protein carbonyls in meat systems: A review. Meat Sci. 2011, 89, 259-279. [CrossRef]

43. Estévez, M. Oxidative damage to poultry: From farm to fork. Poult. Sci. 2015, 94, 1368-1378. [CrossRef]

44. Callura, J.C. Activated Carbon Catalyzed Nitrosamine Formation via Amine Nitrosation. Ph.D. Thesis, Georgia Institute of Technology, Atlanta, GA, USA, 2014.

45. Pacher, P.; Beckman, J.S.; Liaudet, L. Nitric Oxide and Peroxynitrite in Health and Disease. Physiol. Rev. 2007, 87, 315-424. [CrossRef]

46. Arnér, E.S.; Holmgren, A. Physiological functions of thioredoxin and thioredoxin reductase. Eur. J. Biochem. 2000, 267, 6102-6109. [CrossRef]

47. Schmitz, J.; Gilberg, E.; Löser, R.; Bajorath, J.; Bartz, U.; Gütschow, M. Cathepsin B: Active site mapping with peptidic substrates and inhibitors. Bioorganic Med. Chem. 2019, 27, 1-15. [CrossRef] [PubMed]

48. Saura, M.; Zaragoza, C.; McMillan, A.; Quick, R.A.; Hohenadl, C.; Lowenstein, J.M.; Lowenstein, C.J. An antiviral mechanism of nitric oxide: Inhibition of a viral protease. Immunity 1999, 10, 21-28. [CrossRef]

49. Aro Aro, J.M.; Nyam-Osor, P.; Tsuji, K.; Shimada, K.; Fukushima, M.; Sekikawa, M. The effect of starter cultures on proteolytic changes and amino acid content in fermented sausages. Food Chem. 2010, 119, 279-285. [CrossRef]

50. Casaburi, A.; Di Monaco, R.; Cavella, S.; Toldrá, F.; Ercolini, D.; Villani, F. Proteolytic and lipolytic starter cultures and their effect on traditional fermented sausages ripening and sensory traits. Food Microbiol. 2008, 25, 335-347. [CrossRef]

51. Gallego, M.; Mora, L.; Escudero, E.; Toldrá, F. Bioactive peptides and free amino acids profiles in different types of European dry-fermented sausages. Int. J. Food Microbiol. 2018, 276, 71-78. [CrossRef] [PubMed]

52. Candogan, K.; Wardlaw, F.B.; Acton, J.C. Effect of starter culture on proteolytic changes during processing of fermented beef sausages. Food Chem. 2009, 116, 731-737. [CrossRef] 